\title{
A New Furanoheliangolide Sesquiterpene Lactone from Calea pinnatifida (R. Br.) Less. (Asteraceae) and Evaluation of Its Trypanocidal and Leishmanicidal Activities
}

\author{
Tamires Cardoso Lima, ${ }^{a}$ Rafaela de Jesus Souza, ${ }^{a}$ Milene Hoehr de Moraes, ${ }^{b}$ \\ Mário Steindel ${ }^{b}$ and Maique Weber Biavatti*,a
}

\begin{abstract}
${ }^{a}$ Departamento de Ciências Farmacêuticas, CCS and ${ }^{b}$ Departamento de Microbiologia, Imunologia e Parasitologia, CCB, Universidade Federal de Santa Catarina (UFSC), 88040-900 Florianópolis-SC, Brazil
\end{abstract}

\begin{abstract}
Calea pinnatifida (R. Br.) Less. is commonly known in Brazil as "cipó-cruz", "quebra-tudo" or "aruca". This species is employed in folk medicine as giardicidal, amoebicidal and to treat digestive disorders. The present paper describes the isolation and structure determination of a new furanoheliangolide sesquiterpene lactone named 11,13-dihydroxy-calaxin, in addition to seven known compounds: ethyl caffeate, vanillin, 12-hydroxy-encecalin, phytol, 3,4-di- $O$-caffeoylquinic acid, 3,5-di- $O$-caffeoylquinic acid and 4,5-di- $O$-caffeoylquinic acid from the ethanol extract of C. pinnatifida leaves. Additionally, 11,13-dihydroxy-calaxin, vanillin, 12-hydroxy-encecalin, phytol, 3,4-di- $O$-caffeoylquinic acid, 4,5-di- $O$-caffeoylquinic acid and the mixture of 3,4-di- $O$ caffeoylquinic, 3,5-di- $O$-caffeoylquinic and 4,5-di- $O$-caffeoylquinic acids were assayed against the amastigote forms of Leishmania amazonensis and Trypanosoma cruzi, and the sesquiterpene lactone 11,13-dihydroxy-calaxin exhibited a promising trypanocidal and leishmanicidal activity, displaying $\mathrm{IC}_{50}$ values of 5.27 and $8.30 \mu \mathrm{M}$, respectively.
\end{abstract}

Keywords: Calea pinnatifida, furanoheliangolide, phenolic compounds, leishmanicidal, trypanocidal

\section{Introduction}

Leishmaniasis and Chagas' disease constitute serious health care problems, mostly in Sub-Saharan Africa, Latin America and Middle East Asia. These parasitic diseases are caused by kinetoplastid protozoan of the genus Leishmania and Trypanosoma, respectively, and are responsible for substantial global morbidity, mortality, economic adversity and huge health care costs. ${ }^{1,2}$ The available chemotherapy for the treatment of these illnesses presents important limitations, including partial efficacy, toxicity, side effects, long-term therapies and high number of resistance cases, resulting in treatment failure. ${ }^{3}$ Thus, there is an urgent demand for the discovery of new antiprotozoal compounds and/or the development of novel therapeutic strategies which are safer, effective, accessible and less toxic. In this context, the natural products from plants, in particular, represent a remarkable source to furnish new bioactive substances. ${ }^{4,5}$

Calea pinnatifida (R. Br.) Less. (Heliantheae, Asteraceae), popularly known in Brazil as "cipó-cruz", "quebra-tudo" or "aruca" ${ }^{6,7}$ is a plant commonly utilized in popular medicine as giardicidal, amoebicidal and to treat digestive problems. ${ }^{7-9}$

*e-mail: maique.biavatti@ufsc.br, maique_wb@hotmail.com
To the best of our knowledge, few chemical and biological works have been performed with this species. Previous phytochemical studies on aerial parts and leaves from C. pinnatifida led to the isolation and identification of one polyacetylene, one sesquiterpene lactone, fatty acid esters, steroids, benzoic acid derivatives ${ }^{10,11}$ and chromenes. ${ }^{6}$ Furthermore, it has also been reported antiproliferative and leishmanicidal properties for some of its extracts (dichloromethane and ethanol) or chemical constituents (sesquiterpene lactones and chromenes). ${ }^{6,12}$

Thus, the main goals of the present study were to explore the chemical composition from the ethanol extract of the leaves of $C$. pinnatifida, as well as to evaluate the in vitro trypanocidal and leishmanicidal activities of the isolated compounds against intracellular forms (amastigotes) of Trypanosoma cruzi and Leishmania amazonensis.

\section{Experimental}

General experimental procedures

Melting points were determined on a Microquímica MQAPF-301 melting point apparatus. Optical rotation was measured in $\mathrm{MeOH}$ using a Schmidt-Haensch 
Polartronic E polarimeter. All NMR analysis $\left({ }^{1} \mathrm{H},{ }^{13} \mathrm{C}\right.$, correlation spectroscopy (COSY), nuclear Overhauser spectroscopy (NOESY), heteronuclear single quantum correlation (HSQC) and heteronuclear multiple bond correlation (HMBC)) were carried out employing Bruker Fourier 300 UltraShield, Bruker AVANCE-400 and/or Ascend 600 spectrometers, operating at 300, 400 and $600 \mathrm{MHz}$ for ${ }^{1} \mathrm{H}$; and 75,100 and $150 \mathrm{MHz}$ for ${ }^{13} \mathrm{C}$, respectively. $\mathrm{CDCl}_{3}$, acetone- $d_{6}$ or methanol- $d_{4}$ with TMS as internal standard $(0.00 \mathrm{ppm})$ were used as solvents for acquisition of the NMR spectra. Chemical shifts $(\delta)$ were given in ppm and coupling constants $(J)$ were expressed in hertz $(\mathrm{Hz})$. High-resolution electrospray ionization mass spectra (HRESIMS) were measured on an Exactive ${ }^{\mathrm{TM}}$ Plus Orbitrap mass spectrometer (Thermo Fisher Scientific) and/or Xevo ${ }^{\circledR}$ G2-XS QTof mass spectrometer (Waters). Preparative high-performance liquid chromatography (HPLC) was performed on a Shimadzu HPLC system (Kyoto, Japan) equipped with two LC-10AD pumps, SCL-10ADVP system controller, SPD-10AV UV detector and manual injection system, using a $\mathrm{C} 18$ column Luna type $\left(10 \mu \mathrm{m}, 250 \times 10 \mathrm{~mm}\right.$, Phenomenex $\left.{ }^{\oplus}\right)$. Medium pressure liquid chromatographic (MPLC) separation was carried out using an FMI fluid metering lab pump, model QSY (Fluid Metering Inc., Syosset, NY). Silica gel (230-400 mesh) used for column chromatography and vacuum liquid chromatography was obtained from Vetec, Brazil; analytical TLC and silica gel RP-18 (240-400 mesh) were purchased from Silicycle; and Sephadex LH-20 was obtained from Tedia Brazil, Brazil.

\section{Collection of plant material}

C. pinnatifida (R. Br.) Less. leaves were collected at the "Costa da Lagoa", Florianópolis, Santa Catarina, Brazil, in June 2013. Botanical identification and authentication of the plant material were performed by PhD John F. Pruski, New York Botanical Garden, and specimen samples are deposited in the Missouri Botanical Garden Herbarium, St. Louis, Missouri, USA (No: MO-2383318) and in the Rio de Janeiro Botanical Garden Herbarium, Rio de Janeiro, Brazil (No: RB00906349).

\section{Extraction and isolation of the chemical constituents}

Fresh leaves from $C$. pinnatifida $(2.6 \mathrm{~kg})$ were cut into small irregular pieces with a scissors and submitted to maceration with ethanol $92 \%$ for 15 days at room temperature (ca. $25^{\circ} \mathrm{C}$ ) until exhaustion (solvent was renewed four times). The solvent was concentrated using a rotary evaporator at $40^{\circ} \mathrm{C}$ under reduced pressure to afford $142.0 \mathrm{~g}$ of a dark green crude extract. Crude extract was solubilized in a minimum volume of $\mathrm{H}_{2} \mathrm{O}$ and sequentially partitioned with hexane $(5 \times 500 \mathrm{~mL})$, dichloromethane $(4 \times 500 \mathrm{~mL})$, and ethyl acetate $(3 \times 500 \mathrm{~mL})$, to yield hexane $(68.5 \mathrm{~g})$, dichloromethane $(7.6 \mathrm{~g})$ and ethyl acetate $(5.9 \mathrm{~g})$ phases, as well as a residual aqueous fraction that was lyophilized to give a hygroscopic solid $(60.0 \mathrm{~g})$.

Dichloromethane fraction ( $7.6 \mathrm{~g})$ was subjected to vacuum liquid chromatography (VLC) on $\mathrm{SiO}_{2}$ gel and eluted with hexane, acetone and $\mathrm{MeOH}$ (pures or in binaries mixtures), affording ten sub-fractions (A-J). An aliquot of sub-fraction D (500.0 mg) was purified by column chromatography (CC) on silica gel using gradient elution with hexane, $\mathrm{CHCl}_{3}$ and EtOAc to give 158 fractions of $40 \mathrm{~mL}$ each. Fractions F69-78 (194.4 mg) and F84-89 (91.3 mg) were re-chromatographed over Sephadex LH-20 with $\mathrm{CHCl}_{3}$ and acetone, respectively, affording $56.3 \mathrm{mg}$ of the compound 11,13-dihydroxy-calaxin (1) and $17.5 \mathrm{mg}$ of ethyl caffeate (2). Fractions F32-33, eluted with pure $\mathrm{CHCl}_{3}$, yielded $7.0 \mathrm{mg}$ of a compound with satisfactory purity grade, vanillin (3). In addition, sub-fractions $B$ and $C$ were reunited $(222.0 \mathrm{mg}$ ) and submitted to CC using hexane-acetone with gradual increases in polarity to give 91 fractions of $50 \mathrm{~mL}$ each. Fractions F44-50 (21.3 mg), after successive preparative TLC (hexane-acetone 75:25, v/v), afforded $3.8 \mathrm{mg}$ of a yellow oil, 12-hydroxy-encecalin (4). Yet, fractions F31-37 were combined to give $8.7 \mathrm{mg}$ of the phytol (5).

Subsequently, a part of ethyl acetate fraction ( $4.9 \mathrm{~g})$ was further chromatographed by VLC on silica gel and the elution was carried out using a solvent gradient $\left(\mathrm{CH}_{2} \mathrm{Cl}_{2}\right.$ with increasing proportions of EtOAc, followed by EtOAc with increasing proportions of $\mathrm{MeOH}$ ), obtaining eight sub-fractions (A-H). An aliquot of sub-fraction $\mathrm{E}$ $(800.0 \mathrm{mg}$ ) was purified by Sephadex LH-20 using acetone$\mathrm{MeOH}$ (1:1) as mobile phase to afford 37 fractions of $25 \mathrm{~mL}$ each. An aliquot of the fractions F16-19 (60 mg) was submitted to successive preparative HPLC performed under isocratic conditions at a flow rate of $1.5 \mathrm{~mL} \mathrm{~min}^{-1}$ with a mobile phase consisting of $\mathrm{ACN}-\mathrm{H}_{2} \mathrm{O}(20: 80, \mathrm{v} / \mathrm{v})$ containing $1 \%$ formic acid and UV detection at $325 \mathrm{~nm}$, yielding the 3,4-di- $O$-caffeoylquinic acid $(6)(6.4 \mathrm{mg})$ and 4,5-di- $O$-caffeoylquinic acid $(\mathbf{8})(10.3 \mathrm{mg})$, respectively. Finally, sub-fraction C (126.5 mg) was subjected to an MPLC over reverse phase RP-18 utilizing $\mathrm{H}_{2} \mathrm{O}-\mathrm{MeOH}$ mixtures as mobile phase to afford 73 fractions of $25 \mathrm{~mL}$ each. Fractions F50-53, eluted with $\mathrm{H}_{2} \mathrm{O}-\mathrm{MeOH}(60: 40)$, gave $22.7 \mathrm{mg}$ of the 3,5-di- $O$-caffeoylquinic acid (7).

\section{Spectroscopic data}

11,13-Dihydroxy-calaxin (1)

White solid; m.p. $144.5-146.0^{\circ} \mathrm{C} ;[\alpha]_{\mathrm{D}}^{25}=-0.733(\mathrm{MeOH}$; 
c $0.013 \mathrm{~g} \mathrm{~mL}^{-1}$; ca. $\left.25^{\circ} \mathrm{C}\right) ;{ }^{1} \mathrm{H}$ NMR (600 MHz, $\mathrm{CDCl}_{3}$ ), see Table 1; ${ }^{13} \mathrm{C}$ NMR (150 MHz, $\mathrm{CDCl}_{3}$ ), see Table 1; HRMS (pESI) $m / z$, calcd. for $\mathrm{C}_{19} \mathrm{H}_{23} \mathrm{O}_{8}[\mathrm{M}+\mathrm{H}]^{+}: 379.1393$, found: 379.1379; HRMS (nESI) $\mathrm{m} / z$, calcd. for $\mathrm{C}_{19} \mathrm{H}_{21} \mathrm{O}_{8}[\mathrm{M}-\mathrm{H}]^{-}$: 377.1236, found: 377.1234 .

\section{Trypanocidal and leishmanicidal screening}

The trypanocidal and leishmanicidal assays of the compounds $1,3-5,6,8$ and the mixture of $6+7+8$ were performed as previously described by Lima et al. ${ }^{13}$

Human monocytic leukemia TPH-1 cell line (ATCC TIB202) was grown in 96-well plates containing RPMI-1640 medium in absence of phenol red (Sigma-Aldrich Co., St. Louis, MO, USA) and supplemented with $10 \%$ bovine fetal serum (FBS) (Life Technologies, USA), $12.5 \mathrm{mM}$ HEPES, Glutamax $(2 \mathrm{mM})$ and the antibiotics penicillin $\left(100 \mathrm{U} \mathrm{mL}^{-1}\right)$ and streptomycin $\left(100 \mu \mathrm{g} \mathrm{m}^{-1}\right)$. The cell culture was maintained at $37{ }^{\circ} \mathrm{C}$ in a humidified $5 \% \mathrm{CO}_{2}$ atmosphere. L. amazonensis MHOM/BR/77/LTB0016 promastigotes, expressing $\beta$-galactosidase, were grown in
Schneider's insect medium (Sigma Chemical Co., St. Louis, MO, USA) and supplemented with 5\% heat inactivated FBS and $2 \%$ of human urine at $26^{\circ} \mathrm{C}$.

To perform the screening of the leishmanicidal activity against intracellular amastigotes of L. amazonensis, THP-1 cells $\left(3.0 \times 10^{4}\right.$ per well $)$ were cultivated in 96-well plates using the RPMI-1640 medium supplemented as described previously, treated with $100 \mathrm{ng} \mathrm{mL}^{-1}$ of phorbol 12-myristate 13 -acetate (PMA) at $37^{\circ} \mathrm{C}$ in a $5 \% \mathrm{CO}_{2}$ for $72 \mathrm{~h}$, to allow THP-1 cells differentiation into non-dividing macrophages. ${ }^{14}$

Four days culture promastigotes $\left(4.0 \times 10^{6}\right.$ parasites per $\mathrm{mL}$ ) were washed with phosphate buffered saline (PBS), pH 7.4, and incubated in RPMI-1640 medium supplemented with $10 \%$ human $\mathrm{AB}^{+}$serum heatinactivated at $34{ }^{\circ} \mathrm{C}$ for $1 \mathrm{~h}$ to parasite opsonization. THP-1 cells were incubated with a parasite:cell ratio of $10: 1$ for $3 \mathrm{~h}$ at $34{ }^{\circ} \mathrm{C}\left(\mathrm{CO}_{2} 5 \%\right)$. After this period, non-adherent parasites were removed by one wash with PBS and infected cells were incubated with $180 \mu \mathrm{L}$ of complete supplemented RPMI-1640 medium for another

Table 1. ${ }^{1} \mathrm{H}(600 \mathrm{MHz})$ and ${ }^{13} \mathrm{C}(150 \mathrm{MHz}) \mathrm{NMR}$ data for compound $\mathbf{1}\left(\mathrm{CDCl}_{3}\right)$

\begin{tabular}{|c|c|c|c|c|}
\hline No. & $\delta$ (mult., $J \mathrm{~Hz}$ ) & ${ }^{1} \mathrm{H}-{ }^{1} \mathrm{H}$ COSY & $\delta(\mathrm{HSQC})$ & HMBC \\
\hline 1 & - & - & 205.4 & - \\
\hline 2 & $5.59(\mathrm{br} \mathrm{s}, 1 \mathrm{H})$ & - & 103.7 & $1 / 3 / 4 / 10$ \\
\hline 3 & - & - & 185.2 & - \\
\hline 4 & - & - & 130.9 & - \\
\hline 5 & $6.02(\mathrm{dq}, 1 \mathrm{H}, J 3.6,1.8)$ & $6 / 15$ & 132.9 & $3 / 7$ \\
\hline 6 & $5.17(\mathrm{ddq}, 1 \mathrm{H}, J 4.2,3.6,1.8)$ & $5 / 7 / 15$ & 75.9 & $4 / 5 / 7 / 8 / 12$ \\
\hline 7 & $3.40(\mathrm{dd}, 1 \mathrm{H}, J 4.2,2.2)$ & $6 / 8$ & 54.9 & $5 / 6 / 8 / 9 / 11 / 12$ \\
\hline 8 & $5.09(\mathrm{ddd}, 1 \mathrm{H}, J 4.4,2.9,2.2)$ & $7 / 9 \mathrm{a} / 9 \mathrm{~b}$ & 68.4 & $6 / 7 / 9 / 10 / 11 / 1$ \\
\hline $9 \mathrm{a}$ & $2.54(\mathrm{dd}, 1 \mathrm{H}, J 15.2,4.4)$ & $8 / 9 \mathrm{~b}$ & 43.4 & $1 / 7 / 8 / 10 / 14$ \\
\hline $9 b$ & $2.34(\mathrm{dd}, 1 \mathrm{H}, J 15.2,2.9)$ & $8 / 9 a$ & 43.4 & $1 / 7 / 10 / 14$ \\
\hline 10 & - & - & 88.4 & - \\
\hline 11 & - & - & 78.1 & - \\
\hline 12 & - & - & 173.4 & - \\
\hline $13 a$ & $4.22(\mathrm{~d}, 1 \mathrm{H}, J 12.7)$ & $13 \mathrm{~b}$ & 45.5 & $7 / 8 / 11 / 12$ \\
\hline $13 b$ & $3.89(\mathrm{~d}, 1 \mathrm{H}, J 12.7)$ & $13 a$ & 45.5 & $7 / 11 / 12$ \\
\hline 14 & $1.47(\mathrm{~s}, 3 \mathrm{H})$ & - & 22.2 & $1 / 8 / 9 / 10$ \\
\hline 15 & $2.08(\mathrm{dd}, 3 \mathrm{H}, J 1.8,1.8)$ & $5 / 6$ & 19.8 & $3 / 4 / 5 / 7$ \\
\hline 1 ' & - & - & 166.7 & - \\
\hline $2^{\prime}$ & - & - & 134.9 & - \\
\hline 3'a & $6.05(\mathrm{dq}, 1 \mathrm{H}, J 2,0,1.0)$ & $3^{\prime} \mathrm{b} / 4^{\prime}$ & 128.1 & $1^{\prime} / 2^{\prime} / 4^{\prime}$ \\
\hline $3^{\prime} \mathrm{b}$ & $5.65(\mathrm{dq}, 1 \mathrm{H}, J 2.0,1.5)$ & $3^{\prime} \mathrm{a} / 4^{\prime}$ & 128.1 & $1^{\prime} / 2^{\prime} / 4^{\prime}$ \\
\hline 4 & $1.86(\mathrm{dd}, 3 \mathrm{H}, J 1.5,1.0)$ & $3^{\prime} \mathrm{a} / 3^{\prime} \mathrm{b}$ & 18.1 & $1^{\prime} / 2^{\prime} / 3^{\prime}$ \\
\hline $\mathrm{OH}$ & $3.26(\mathrm{br} \mathrm{s}, 1 \mathrm{H})$ & - & - & $7 / 11 / 12$ \\
\hline
\end{tabular}

${ }^{1} \mathrm{H}-{ }^{1} \mathrm{H}$ COSY: ${ }^{1} \mathrm{H}-{ }^{1} \mathrm{H}$ correlation spectroscopy; HSQC: heteronuclear single quantum correlation; HMBC: heteronuclear multiple bond correlation. 
$24 \mathrm{~h}$ to allow the transformation of promastigotes into intracellular amastigotes.

The $\beta$-galactosidase Trypanosoma cruzi, Tulahuen strain, ${ }^{15}$ was kindly provided by the Laboratório de Parasitologia Molecular e Celular, Centro de Pesquisas René Rachou, FIOCRUZ, Belo Horizonte, Brazil. Culturederived trypomastigotes raised from infected $\mathrm{L} 929$ cell line were used to infect differentiated THP- $1\left(4.0 \times 10^{4}\right.$ cells per well) in 96-well microplates in a parasite:cell ratio of 3:1 and incubated overnight at $37{ }^{\circ} \mathrm{C}$ with $5 \% \mathrm{CO}_{2}$. The medium containing non-internalized parasites was removed and replaced with $180 \mu \mathrm{L}$ of fresh medium.

Compounds 1, 3-5, 6, 8 and the mixture of $6+7+8$ were dissolved in DMSO $1 \%$ at concentrations ranging from 50 to $1.56 \mu \mathrm{M}$. Infected cell layer was treated by addition of $20 \mu \mathrm{L}$ of each sample followed by incubation at $34{ }^{\circ} \mathrm{C}$ with $5 \% \mathrm{CO}_{2}$ for $48 \mathrm{~h}$. After treatment, cells were carefully washed with PBS and incubated at $37^{\circ} \mathrm{C}$ for $16 \mathrm{~h}$ with $250 \mu \mathrm{L}$ of chlorophenol red- $\beta$-D-galactopyranoside (CPRG) (Sigma-Aldrich Co., St. Louis, MO, USA) at $100 \mu \mathrm{M}$ and Nonidet P-40 0.1\% (NP-40) (Amresco Inc, Solon, Ohio, USA). All assays were performed in triplicate. Optical density was read at 570/630 nm in an Infinite M200 TECAN, Austria. The concentration of each sample that reduced parasite viability by $50 \%$ when compared to untreated control $\left(\mathrm{IC}_{50}\right)$ was estimated by non-linear regression of concentration-response curves. Benznidazole (Sigma) and amphotericin B (Bristol-Myers, Squibb) were utilized as positive control groups for trypanocidal and leishmanicidal assays, respectively, and DMSO $1 \%$ was used as negative control group.

\section{Cell toxicity assay}

THP-1 cells were seeded $\left(6.0 \times 10^{4}\right.$ per well $)$ in 96-well microplates and differentiated with $100 \mathrm{ng} \mathrm{mL}^{-1}$ of PMA. After $72 \mathrm{~h}$ of incubation at $37^{\circ} \mathrm{C}$ in a humidified $5 \% \mathrm{CO}_{2}$ atmosphere, compounds at concentration varying between 500 and $15.6 \mu \mathrm{M}$ or DMSO $1 \%$ (negative control) were added and the cells were incubated again for $72 \mathrm{~h}$ at $37{ }^{\circ} \mathrm{C}\left(\mathrm{CO}_{2} 5 \%\right)$. The cell viability was measured by the colorimetric 3-(4,5-dimethylthiazol2-yl)-2,5-diphenyltetrazolium bromide method (MTT) based on tetrazolium salt reduction by mitochondrial dehydrogenases, and the optical densities were read at $540 \mathrm{~nm}$ in a TECAN Infinite M200 microplate reader immediately after the dissolution of formazan crystals with DMSO. The $\mathrm{CC}_{50}$ value was defined as the concentration of each compound that reduced the absorbance of treated cells by $50 \%$ when compared with the cell control. ${ }^{16}$

\section{Results and Discussion}

The chromatographic fractionation of the dichloromethane and ethyl acetate fractions from the ethanol extract of $C$. pinnatifida leaves led to the isolation and structural characterization of seven known compounds: ethyl caffeate (2), vanillin (3), 12-hydroxy-encecalin (4), phytol (5), 3,4-di- $O$-caffeoylquinic acid (6), 3,5-di- $O$ caffeoylquinic acid (7) and 4,5-di- $O$-caffeoylquinic acid (8), as well as a new furanoheliangolide sesquiterpene lactone (1) (Figure 1). The structures were elucidated by detailed analysis of their physical (m.p.) and spectral data (HRESIMS, 1D and 2D NMR), as well as comparison with similar data reported in the literature..$^{13,17-21}$

The isomeric compounds $\mathbf{6}$ and $\mathbf{8}$ were distinguished from each other based on their tandem mass spectrometry (MS/MS) fragmentation patterns and chromatographic resolution on a reversed phase packing. These isomers were identified according to a hierarchical scheme for characterizing chlorogenic acids that has been previously developed by Clifford et al. ${ }^{19,22-24}$ Figure 2 shows the chromatogram of a sample containing the three isomeric dicaffeoylquinic acids (6, 7 and $\mathbf{8})$.

Compound 1 was obtained from the dichloromethane fraction as a white solid with melting point $=144.5-146.0^{\circ} \mathrm{C}$. Further, this compound appeared as a dark brown spot on TLC after spraying with anisaldehyde-sulphuric acid and heating at $100{ }^{\circ} \mathrm{C}$ for few minutes. Its molecular formula was determined by HRESIMS in both positive and negative ionization modes. The HRESIMS spectrum in positive mode exhibited a molecular ion peak at $\mathrm{m} / \mathrm{z} 379.1379$ $[\mathrm{M}+\mathrm{H}]^{+}$(calcd. for $\mathrm{C}_{19} \mathrm{H}_{23} \mathrm{O}_{8}: 379.1393$ ), and the negative mode HRESIMS spectrum revealed a molecular ion peak at $\mathrm{m} / z$. $377.1234[\mathrm{M}-\mathrm{H}]^{-}$(calcd. for $\mathrm{C}_{19} \mathrm{H}_{21} \mathrm{O}_{8}$ : 377.1236), both compatible with molecular formula $\mathrm{C}_{19} \mathrm{H}_{22} \mathrm{O}_{8}$, corresponding to nine degrees of unsaturation. The ESI-MS/MS spectral data of compound 1 revealed a base ion peak with $m / z, 291\left(\mathrm{C}_{15} \mathrm{H}_{15} \mathrm{O}_{6}\right)$ formed by the

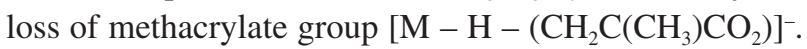
Moreover, there were also produced $m / z 247\left(\mathrm{C}_{14} \mathrm{H}_{15} \mathrm{O}_{4}\right)$ and $m / z 229\left(\mathrm{C}_{14} \mathrm{H}_{13} \mathrm{O}_{3}\right)$ fragment ions, due to the elimination of $\mathrm{CO}_{2}$ and $\mathrm{H}_{2} \mathrm{O}$, respectively. A fragmentation mechanism for the sesquiterpene lactone $\mathbf{1}$ is proposed in the Figure 3.

The ${ }^{1} \mathrm{H}$ NMR spectrum (Table 1) of $\mathbf{1}$ displayed characteristic signals of sesquiterpene lactones common to the genus Calea. ${ }^{25-28}$ Absence of the pair of doublets relative to exomethylene hydrogens provided evidence for the saturation between $\mathrm{C}-11$ and $\mathrm{C}-13$. The pair of doublets resonating at $\delta 4.22(\mathrm{~d}, 1 \mathrm{H}, J 12.7 \mathrm{~Hz}, \mathrm{H}-13 \mathrm{a})$ and $\delta 3.89$ $(\mathrm{d}, 1 \mathrm{H}, J 12.7 \mathrm{~Hz}, \mathrm{H}-13 \mathrm{~b}) / \delta 45.5$, typical of diastereotopic hydrogens attached to the carbinolic carbon, was ascribed 


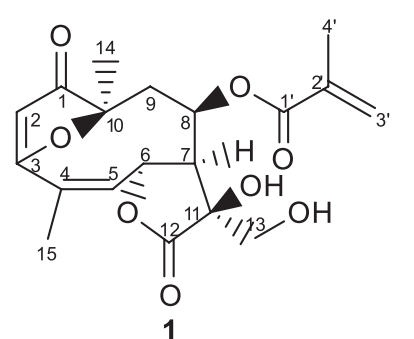<smiles>CCOC(=O)/C=C/c1ccc(O)c(O)c1</smiles>

2<smiles>C/C(=C\CO)CCCC(C)CCCC(C)CCCC(C)C</smiles>

5<smiles>O=C(/C=C/c1ccc(O)c(O)c1)OC1CC(O)C(OC(=O)/C=C/c2ccc(O)c(O)c2)CC(O)(C(=O)O)C1</smiles><smiles>COc1cc(C=O)ccc1O</smiles><smiles>COc1cc2c(cc1C(=O)CO)C=CC(C)(C)O2</smiles><smiles>O=COC1CC(O)(C(=O)O)CC(O)C1OC(=O)/C=C/c1ccc(O)c(O)c1</smiles>

6<smiles>CC=Cc1ccc(O)c(O)c1</smiles><smiles>CC(O)CO</smiles>

8

Figure 1. Chemical structures of the isolated compounds from C. pinnatifida.

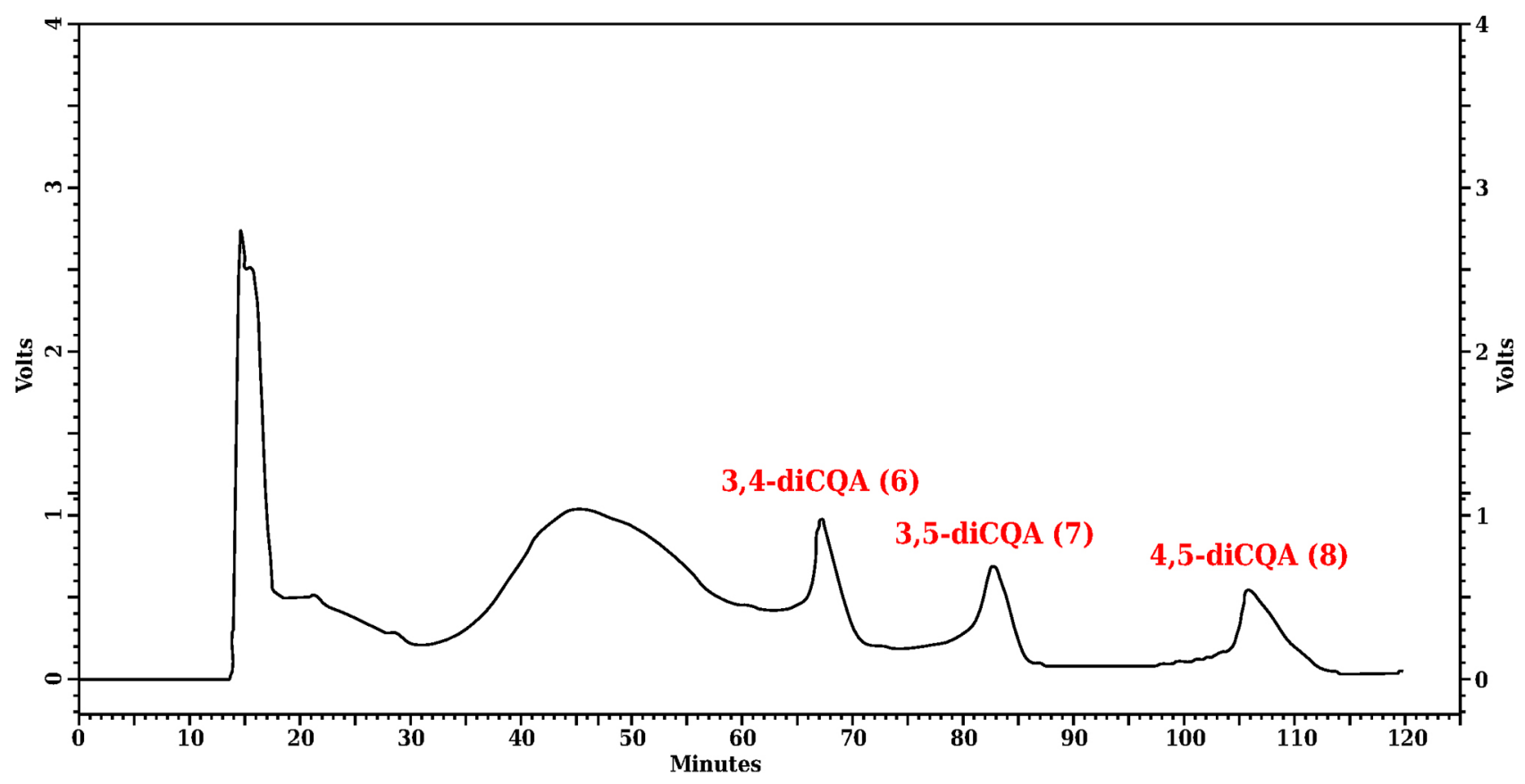

Figure 2. Chromatogram of a sample containing the isomeric dicaffeoylquinic acids 6, 7 and $\mathbf{8}$.

to $\mathrm{H}-13 \mathrm{a}$ and $\mathrm{H}-13 \mathrm{~b}$. A broad singlet at $\delta 5.59$ (brs, $1 \mathrm{H}$, $\mathrm{H}-2) / \delta 103.7$ together with a double quartet at $\delta 6.02(\mathrm{dq}, 1 \mathrm{H}$, $J 3.6,1.8 \mathrm{~Hz}, \mathrm{H}-5) / \delta 132.9$ are consistent with the presence of a sesquiterpene lactone of the furanoheliangolide type. It was also observed in the ${ }^{1} \mathrm{H}$ NMR spectrum two typical signals of oxymethinic hydrogens at $\delta 5.09$ (ddd, $1 \mathrm{H}, J 4.4$, 


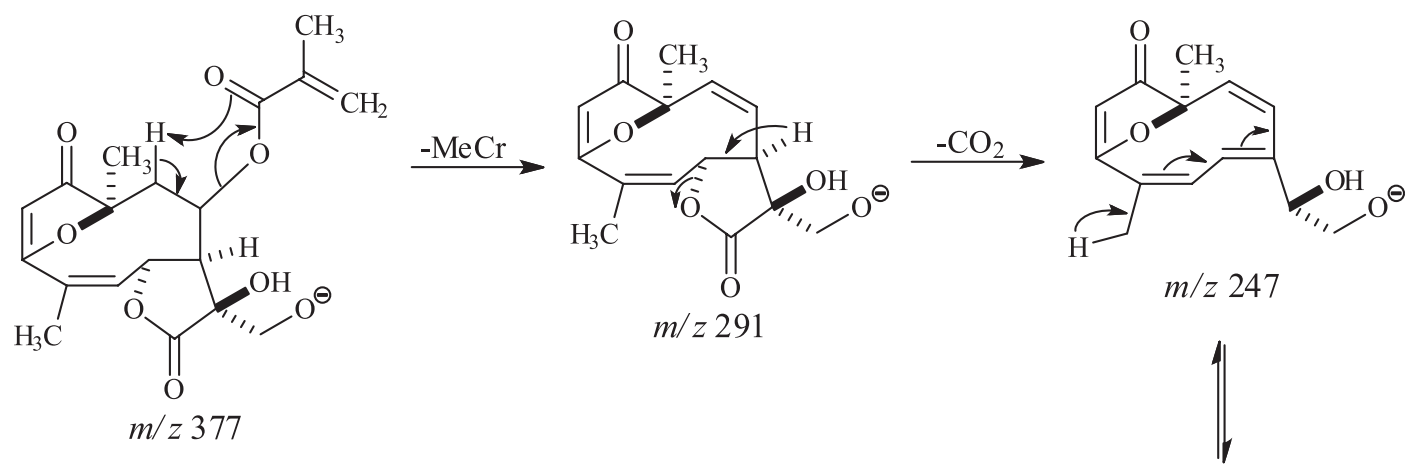

MeCr: methacrylate

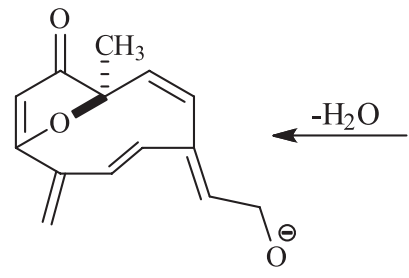

$m / z 229$

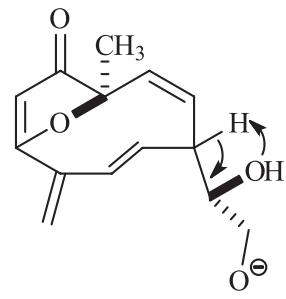

$m / z 247$

Figure 3. Proposed fragmentation mechanism ( $n$ ESI-MS/MS) for compound 1.

2.9, $2.2 \mathrm{~Hz}, \mathrm{H}-8) / \delta 68.4$ and $\delta 5.17(\mathrm{ddq}, 1 \mathrm{H}, J 4.2,3.6$, $1.8 \mathrm{~Hz}, \mathrm{H}-6) / \delta 75.9$, and a methane signal at $\delta 3.40(\mathrm{dd}$, $1 \mathrm{H}, J 4.2,2.2 \mathrm{~Hz}, \mathrm{H}-7) / \delta 54.9$. The coupling constant value $\left(J_{6,7} 4.2 \mathrm{~Hz}\right)$ observed between H-6 and H-7 corroborates the presence of a 6,12 $\alpha$-trans lactonized heliangolide with a cis-4,5-double bond. Additionally, the ester side chain was assigned as a methacrylate group based on three typical signals: two olefinic methylene hydrogens resonating at $\delta 6.05(\mathrm{dq}, 1 \mathrm{H}, J 2.0,1.0 \mathrm{~Hz}, \mathrm{H}-3$ ' a) and $\delta 5.65(\mathrm{dq}, 1 \mathrm{H}$, $\left.J 2.0,1.5 \mathrm{~Hz}, \mathrm{H}-3^{\prime} \mathrm{b}\right) / \delta 128.1$, and an olefinic methyl at $\delta 1.86$ $\left(\mathrm{dd}, 3 \mathrm{H}, J 1.5,1.0 \mathrm{~Hz}, \mathrm{H}-4^{\prime}\right) / \delta 18.1$. The attachment of the ester side chain to the carbon C-8 of the furanoheliangolide skeleton was established based on HMBC correlation from the oxymethinic proton $\mathrm{H}-8$ at $\delta 5.09$ with the carbon signal at $\delta 166.7\left(\mathrm{C}-1^{\prime}\right)$. Figure 4 displays some important ${ }^{1} \mathrm{H}-{ }^{1} \mathrm{H}$ COSY and HMBC correlations of compound $\mathbf{1}$.

The chemical shift values of carbon were obtained by the HSQC and HMBC experiments. HSQC and HMBC correlation maps revealed the presence of 19 $\mathrm{C}$-atom signals, including one lactone carbonyl $(\delta$ 173.4), one $\alpha, \beta$-unsaturated ketone carbonyl ( $\delta$ 205.4), one $\alpha, \beta$-unsaturated ester carbonyl $(\delta 166.7)$, three $\mathrm{sp}^{2}$ olefinic carbons $(\delta 103.7,128.1$ and 132.9), two quaternary olefinic carbons ( $\delta 130.9$ and 134.9), one oxygenated quaternary olefinic carbon $\left(\delta\right.$ 185.2), three $\mathrm{sp}^{3}$ oxygenated carbons $(\delta 45.5,68.4$ and 75.9$)$, two $\mathrm{sp}^{3}$ oxygenated quaternary carbons ( $\delta 78.1$ and 88.4), one methylene $(\delta 43.4)$, one methine $(\delta$ 54.9) and three methyl groups $(\delta 18.1,19.8$ and 22.2) (Table 1).

The relative configurations of stereogenic centers in compound $\mathbf{1}$ were deduced on the basis in the coupling constant values which were correlated with the dihedral angles obtained from Dreiding models and application of the Karplus curve. The relative cis-disposition of $\mathrm{C}(4,5)$ double bond associated with the coupling constant value recorded between $\mathrm{H}-6 / \mathrm{H}-7\left(J_{6,7} 4.2 \mathrm{~Hz}\right)$ indicated a different arrangement for H-6 and H-7. Assuming that H-7 is $\alpha$-oriented, as generally occurs in sesquiterpene lactones isolated from higher plants, ${ }^{29-31}$ it should be concluded a $\beta$-orientation for H-6. Similarly, the small coupling constant observed between $\mathrm{H}-7 / \mathrm{H}-8\left(J_{7,8} 2.2 \mathrm{~Hz}\right)$ suggested a $\beta$-orientation for the methacrylate side chain located at $\mathrm{C}-8$ and $\alpha$-orientation for the oxymethine $\mathrm{H}-8$. The signal corresponding to the H-7 hydrogen has an unusually low chemical shift $(\delta 3.40)$, suggesting that this hydrogen is close to the oxygen of the furan ring. This proximity requires an $\alpha$-orientation for the hydrogens $\mathrm{H}-14$ of methyl group, as occurs in all furanoheliangolide sesquiterpene lactones of known stereochemistry. ${ }^{32-36}$ The analysis of NOESY correlation map (acetone- $d_{6}$ ) allowed us to determine the relative configuration of $\mathrm{C}-11$. Clear NOESY correlation was observed between the methinic proton $\mathrm{H}-7$ ( $\alpha$-oriented) and the methylene hydrogens $\mathrm{H}-13 \mathrm{a}$ and $\mathrm{H}-13 \mathrm{~b}$ attached to $\mathrm{C}-13$ (Supplementary Information). Based on this observation, we can suggest a $\beta$-orientation for the hydroxyl group at $\mathrm{C}-11(\mathrm{C}-\mathrm{OH})$ and an $\alpha$-orientation for the bond between the carbons $\mathrm{C}-11$ and $\mathrm{C}-13$ (Figure 1).

The ${ }^{1} \mathrm{H}$ and ${ }^{13} \mathrm{C}$ NMR data (Table 1 ) of compound $\mathbf{1}$ resembled those of sesquiterpene lactone 11,13-epoxycalaxin previously isolated from C. pilosa ${ }^{18}$ clearly indicating that both compounds present the same skeletal arrangement. These two sesquiterpene lactones differ 
only in the functional group located at the $\mathrm{C}-11$ and C-13 carbons. Compound 1 possess a C-11,13-diol moiety instead of the C-11,13-epoxy moiety present in 11,13-epoxy-calaxin. The existence of a C-11,13-diol moiety was evident by the broad singlet resonating at $\delta 3.26$ (br s, $1 \mathrm{H}, \mathrm{OH}$ ), clearly demonstrating the presence of at least one hydroxyl group in $\mathbf{1}$. Moreover, this moiety was confirmed by the observed HMBC correlations between broadened $\mathrm{OH}$ singlet at $\delta 3.26$ with the carbon signals at $\delta 54.9$ (C-7), 78.1 (C-11) and 173.4 (C-12) (Figure 4). The compound 1 has been identified in the crude extract from $C$. pinnatifida by ultra-high performance liquid chromatography electrospray ionization mass spectrometry (UHPLC-ESI-MS), indicating that this compound isn't a product of ring opening of an epoxide from natural sesquiterpene lactone 11,13-epoxy-calaxin.

Collectively, these data supported the structure of a new furanoheliangolide and allowed us to name compound $\mathbf{1}$ as 11,13-dihydroxy-calaxin [( $3 R, 3 \alpha R, 4 R, 11 \alpha S, Z)-3$ hydroxy-3-(hydroxymethyl)-6,10-dimethyl-2,7-dioxo2,3,3 $\alpha, 4,5,6,7,11 \alpha$-octahydro-6,9-epoxycyclodeca[b] furan-4-yl methacrylate]. This is the first report of furanoheliangolide-type sesquiterpenes in C. pinnatifida, however the occurrence of furanoheliangolide is common in Calea genus. . $^{18,25-28,37-41}$

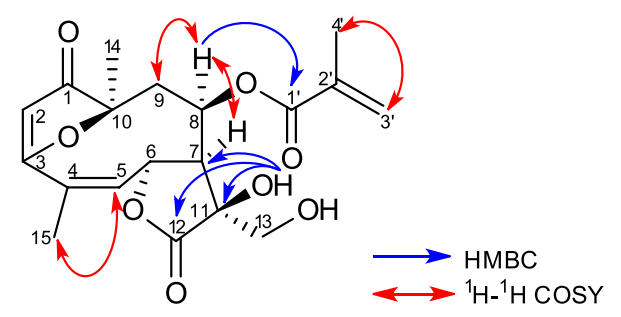

Figure 4. Selected ${ }^{1} \mathrm{H}-{ }^{1} \mathrm{H}$ COSY and HMBC correlations of compound $\mathbf{1}$.

The antiprotozoal activity of compounds 1, 3-5, 6, 8 and the mixture of $6+7+\mathbf{8}$ was examined against intracellular forms (amastigotes) of T. cruzi and L. amazonensis, the etiological agents of the Chagas' disease and cutaneous leishmaniasis, respectively. Compounds $\mathbf{2}$ and $\mathbf{7}$ were not examined because they have been previously tested by Lima et al. ${ }^{13}$ Compound 2 exhibited a $76.06 \%$ inhibitory effect on the growth of $T$. cruzi and $24.53 \%$ on the growth of L. amazonensis, while compound 7 inhibited L. amazonensis amastigotes intracellular growth by $24.53 \%$ and exhibited no activity against $T$. cruzi amastigotes. ${ }^{13}$

The results of the trypanocidal and leishmanicidal assays were measured in terms of percentage of growth inhibition of T. cruzi and L. amazonensis amastigotes, and are described in Table 2 . The capacity of the compounds to inhibit the parasite growth was investigated at $50 \mu \mathrm{M}$, and the
$\mathrm{IC}_{50}$ (50\% inhibitory concentration), $\mathrm{CC}_{50}(50 \%$ cytotoxic concentration) and SI (selectivity index $=\mathrm{CC}_{50} / \mathrm{IC}_{50}$ ) values were estimated only for the most bioactive compounds (\%growth inhibition > 50\%). DMSO $1 \%$ was utilized as negative control and did not affect the growth of the parasites. As positive controls, parasites were treated with benznidazole $20 \mu \mathrm{M}$ and amphotericin B $2 \mu \mathrm{M}$, showing $82.67 \%$ of growth inhibition against T. cruzi and $86.88 \%$ against $L$. amazonensis, respectively.

Compounds 3-5, 6, 8 and the mixture of $6+7+8$ displayed weak or no percentage of inhibition against intracellular amastigotes of both T. cruzi and L. amazonensis, whereas the compound $\mathbf{1}$ exhibited a strong leishmanicidal and trypanocidal effect, inhibiting the intracellular parasite growth in 81.81 and $94.30 \%$, respectively. Furthermore, this compound displayed $\mathrm{IC}_{50}$ values of $5.27 \pm 0.19$ and $8.30 \pm 0.57 \mu \mathrm{M}$ for $T$. cruzi and L. amazonensis, respectively, showing a promising trypanocidal and leishmanicidal activity.

Table 2. In vitro leishmanicidal and trypanocidal activities of the compounds 1, 3-5, 6 and 8

\begin{tabular}{lcc}
\hline $\begin{array}{l}\text { Compounds tested } \\
\text { Concentration }\end{array}$ & $\begin{array}{c}\text { \%Growth } \\
\text { inhibition } \pm \text { SD } \\
\text { L. amazonensis } \\
\text { amastigotes }\end{array}$ & $\begin{array}{c}\text { \%Growth } \\
\text { inhibition } \pm \text { SD } \\
\text { T. cruzi } \text { amastigotes }\end{array}$ \\
\hline $\mathbf{1}$ & $81.81 \pm 2.12$ & $94.30 \pm 0.39$ \\
$\mathbf{3}$ & $12.94 \pm 0.45$ & $2.36 \pm 0.57$ \\
$\mathbf{4}$ & no activity & $4.74 \pm 0.82$ \\
$\mathbf{5}$ & no activity & $2.31 \pm 0.52$ \\
$\mathbf{6}$ & $3.42 \pm 0.11$ & $1.70 \pm 0.22$ \\
$\mathbf{8}$ & $3.17 \pm 0.39$ & $1.82 \pm 0.13$ \\
Mixture $\mathbf{6}+\mathbf{7}+\mathbf{8}$ & $3.11 \pm 0.45$ & no activity \\
DMSO 1\% & 0 & 0 \\
Benznidazole $20 \mu \mathrm{M}$ & - & $82.67 \pm 0.88$ \\
Amphotericin B $2 \mu \mathrm{M}$ & $86.88 \pm 3.83$ & - \\
\hline
\end{tabular}

Regarding the cytotoxic potential on THP-1 cells, the sesquiterpene lactone 11,13-dihydroxy-calaxin presented a lower selectivity for the parasite cells $\left(\mathrm{CC}_{50}<15.60\right)$, resulting in low selectivity index (SI value not determined). Cytotoxicity $\left(\mathrm{CC}_{50}\right)$ and the selectivity index (SI) has not been calculated for the other compounds because all exhibited a weak leishmanicidal and trypanocidal effect (\%growth inhibition $<50 \%$ ). Cytotoxicity is an essential parameter for the initial stages of the development de new drugs, once that it determines the in vitro selectivity for the parasites and whether the bioactive compounds cause toxic effects on mammalian host cells. Thus, the cytotoxicity tests with natural products, mainly plant species, are an important 
strategy because natural products constitute a promising source of new bioactive compounds, revealing chemical scaffolds important for the discovery and development of new and selective antiprotozoal. ${ }^{42,43}$

\section{Conclusions}

The phytochemical investigation from $C$. pinnatifida leaves led to the isolation and characterization of a new furanoheliangolide sesquiterpene lactone in addition to seven known compounds. It is important to note that all the isolated compounds are reported here for the first time for the $C$. pinnatifida species. Moreover, the antiprotozoal assays shown that the furanoheliangolide 11,13-dihydroxy-calaxin presented a remarkable trypanocidal and leishmanicidal effect against both T. cruzi and L. amazonensis amastigotes.

\section{Supplementary Information}

1D and 2D NMR, and HRESIMS data of compound $\mathbf{1}$ (Figures S1-S13), and TLC of the compounds 6 and 8 (Figure S14) are available free of charge at http://jbcs.sbq.org.br as PDF file.

\section{Acknowledgments}

The authors are thankful to Mr. César Simionato and $\mathrm{PhD}$ John Pruski for help in the plant collection and identification, respectively; MSc Rosana Casoti, PhD Fernando Batista da Costa and PhD Louis Pergaud Sandjo for mass spectrometry analysis; and CAPES/CNPq for financial support. Part of this work was performed within the Research Network Natural Products against Neglected Diseases (ResNetNPND).

\section{References}

1. Stuart, K.; Brun, R.; Croft, S.; Fairlamb, A.; Gürtler, R.E.; McKerrow, J.; Reed, S.; Tarleton, R.; J. Clin. Invest. 2008, 118, 1301.

2. Yamanaka, C. N.; Raquel, B. G.; Celso Jr., O. R.; Eger, I.; Kessler, R. L.; Tonini, M. L.; Moraes, M. H.; Araujo, D. P.; Zuanazzi, J. A.; Almeida, M. V.; Steindel, M.; Chem. Biol. Drug Des. 2013, 82, 697.

3. Sulsen, V. P.; Fernanda, M. F.; Cazorla, S. I.; Anesini, C. A.; Malchiodi, E. L.; Freixa, B.; Vila, R.; Muschietti, L. V.; Martino, V. S.; Antimicrob. Agents Chemother. 2008, 52, 2415.

4. Godinho, J. L.; Simas-Rodrigues, C.; Silva, R.; Ürmenyi, T. P.; de Souza, W.; Rodrigues, J. C.; Int. J. Antimicrob. Agents 2012, 39, 326.
5. Sifaoui, I.; López-Arencibia, A.; Martín-Navarro, C. M.; Chammem, N.; Reyes-Batlle, M.; Mejri, M.; Lorenzo-Morales, J.; Abderabba, M.; Piñero, J. E.; Exp. Parasitol. 2014, 141, 106.

6. Lima, T. C.; Santos, A. D. C.; Costa, D. T. M.; Souza, R. J.; Barison, A.; Steindel, M.; Biavatti, M. W.; Braz. J. Pharmacogn. 2015, $25,7$.

7. Mors, W. B.; Rizzini, C. T.; Pereira, N. A.; Medicinal Plants of Brazil; Reference Publications: Algonac, 2000.

8. Malhado Filho; Arq. Cir. Clin. Exp. 1947, 31, 43.

9. Prusk, J. F.; Urbatsch, L. E.; Brittonia 1988, 40, 341.

10. Ferreira, Z. S.; Roque, N. F.; Gottlieb, O. R.; Oliveira, F.; Gottleib, H. E.; Phytochemistry 1980, 19, 1481.

11. Ferreira, Z. S.; Roque, N. F.; Gottlieb, O. R.; Oliveira, F.; Ciênc. Cult. 1980, 32, 83.

12. Marchetti, G. M.; Silva, K. A.; Santos, A. N.; Sousa, I. M. O.; Tinti, S. V.; Figueira, G. M.; Foglio, M. A.; Carvalho, J. E.; J. Exp. Pharmacol. 2012, 4, 157.

13. Lima, T. C.; Souza, R. J.; Santos, A. D.; Moraes, M. H.; Biondo, N. E.; Barison, A.; Steindel, M.; Biavatti, M. W.; Nat. Prod. Res. 2015, 16, 1.

14. Schwende, H.; Fitzke, E.; Ambs, P.; Dieter, P.; J. Leukoc. Biol. 1996, 59, 555.

15. Buckner, F.; Verlinde, C. L. M. J.; la Flamme, A. C.; van Voorhis, W. C.; Antimicrob. Agents Chemother. 1996, 40, 2592.

16. Cheng, J.; Sun, N.; Zhao, X.; Niu, L.; Song, M.; Sun, Y.; Jiang, J.; Guo, J.; Bai, Y.; He, J.; Li, H.; J. Microbiol. Biotechnol. 2013, 23, 1076.

17. Bohlmann, F.; Jakuponic, J.; Phytochemistry 1978, 17, 1677.

18. Bohlmann, F.; Fritz, U.; Kings, R. M.; Robinson, H.; Phytochemistry 1981, 20, 743.

19. Clifford, M. N.; Knight, S.; Kuhnert, N.; J. Agric. Food Chem. 2005, 53, 3821.

20. França, V. C.; Vieira, K. V. M.; Lima, E. O.; Barbosa-Filho, J. M.; da-Cunha, E. V. L.; da Silva, M. S.; Rev. Bras. Farmacogn. 2005, 15, 326.

21. Ragasa, C. Y.; Javier, E. S. C.; Tan, A. G.; Philipp. J. Sci. 2003, 132, 21.

22. Clifford, M. N.; Johnston, K. L.; Knight, S.; Kuhnert, N.; J. Agric. Food Chem. 2003, 51, 2900.

23. Clifford, M. N.; Wu, W.; Kirkpatrick, J.; Kuhnert, N.; J. Agric. Food Chem. 2007, 55, 929.

24. Clifford, M. N.; Kirkpatrick, J.; Kuhnert, N.; Roorendaal, H.; Salgado, P. R.; Food Chem. 2008, 106, 379.

25. Bohlmann, F.; Gupta, R. K.; Jakupovic, J.; King, R. M.; Robinson, H.; Phytochemistry 1982, 21, 2899.

26. Bohlmann, F.; Gupta, R. K.; King, R. M.; Robinson, H.; Phytochemistry 1982, 21, 2593.

27. Bohlmann, F.; Gupta, R. K.; King, R. M.; Robinson, H.; Phytochemistry 1982, 21, 2117.

28. Bohlmann, F.; Mathur, R.; Jakupovic, J.; Gupta, R. K.; King, R. M.; Robinson, H.; Phytochemistry 1982, 21, 2045. 
29. Fisher, N. H. In Biochemistry of the Mevalonic Acid Pathway to Terpenoids; Towers, G. H. N.; Stafford, H. A., eds.; Springer: New York, 1990, p. 161.

30. Ibrahim, M.; Farooq, T.; Hussain, N.; Hussain, A.; Gulzar, T.; Hussain, I.; Akash, M. S.; Rehmani, F. S.; Chem. Cent. J. 2013, $7,1$.

31. Shi, Z. R.; Shen, Y. H.; Zhang, X. Y.; Fang, X.; Zeng, R. T.; Liu, Q. X.; Zhuo, Z. G.; Feng, F.; Zhang, W. D.; RSC Adv. 2015, 5, 91640.

32. De Vivar, A. R.; Guerrero, C.; Díaz, E.; Bratoeff, E. A.; Jiménez, L.; Phytochemistry 1976, 15, 525.

33. Passreiter, C. M.; Stöber, S.; Ortega, A.; Z. Naturforsch. 2000, $55 c, 1026$.

34. Ober, A. G.; Urbatsch, L. E.; Fischer, N. H.; Phytochemistry 1986, 25, 467.

35. Sakamoto, H. T.; Flausino, D.; Castellano, E. E.; Stark, C. B. W.; Gates, P. J.; Lopes, N. P.; J. Nat. Prod. 2003, 66, 693.

36. Triana, J.; Phytochemistry 1984, 23, 2072.

37. Bohlmann, F.; Bapuji, M.; King, R. M.; Robinson, H.; Phytochemistry 1981, 21, 1164.
38. Bohlmann, F.; Gupta, R. K.; Jakupovic, J.; King, R. M.; Robinson, H.; Phytochemistry 1981, 20, 1635.

39. Fisher, N. H.; Lee, I. Y.; Fronczek, F. R.; J. Nat. Prod. 1984, $47,419$.

40. Ober, A. G.; Urbatsch, L. E.; Fischer, N. H.; Phytochemistry 1986, 25, 467.

41. Ortega, A.; Lopez, J. C.; Maldonado, E.; Phytochemistry 1989, 28, 2735.

42. Brenzan, M. A.; Nakamura, C. V.; Dias Filho, B. P.; UedaNakamura, T.; Young, M. C.; Cortez, A. G. D.; Parasitol. Res. 2007, 101, 715.

43. Chávez, J. H.; Leal, P. C.; Yunes, R. A.; Nunes, R. J.; Barardi, C. R. M.; Pinto, A. R.; Simões, C. M. O.; Zanetti, C. R.; Vet. Microbiol. 2006, 116, 53.

Submitted: February 26, 2016

Published online: June 21, 2016 